\title{
The geo-cultural and geo-linguistic dimension of media
}

\author{
Roland Lami \\ Department of Applied Social Sciences, European University of Tirana, Albania \\ E-mail address: roland.lami@uet.edu.al
}

\begin{abstract}
Besides the potential advancement of technology, the global and local communication is framing itself within bigger dimensions. The messages delivered by actual media means and the intensive exchange of experiences and ideas are conceived by the communication specialists as the most effective ways to configure the positions and therefore, are offering new models for solutions to challenges of the life. Under the influence of electronic media, highly urbanized areas like remote provinces and lost, suffer the impact of a communication process only, support on standardization, repeatability and homogeneity. This influence increases much more in terms of a social organization nonsolid and isolation relative to individuals. Also, under the influence of technology, communication transcends, institutional and legal barriers by providing to citizen unlimited messages in time and space. This dimension will be limited to some form of analysis within the Albanian-speaking scope. As we already know, some powerful media companies based in Tirana are dominating the Albanianspeaking trade, deploying a business with clear geo-cultural and geo-linguistic orientation. Precisely, these cultural products are having national nuances and are stimulating homogenous tendencies of the thought, "threatening" the cultural nuances of diverse social groups included in the communication process. The "center" that is producing linguistic and cultural standards is enforcing the "periphery", inflicting the demonstration of nuances, dialects, mentalities and different points of view. This mode, cannot avoid hegemonic reproduction phenomenon due to the effect structuring speech by "mighty" you have the opportunity to deliver the and transmit it. Thereupon, social group, that has access to the media reaches impose cultural patterns off majority of the population.
\end{abstract}

Keywords: Technology; center; periphery; national symbolism; electronics media; homogeneity

\section{INTRODUCTION}

Thanks to the technology, nowadays the media has overcome limits of the past, institutional and legal barriers by offering to the citizens (receivers) unlimited messages in time and space [1]. Under the influence of the media, cities and villages are affected by the process of communication, based on standardization, repeatability and homogeneity [2]. Media grows even more influential in terms of a vague economic-political exchange, of a lack of solid social organization and of a relative isolation of individuals [3].

In this way, the role of electronic media in Albanian-speaking territories is pivotal to this paper analysis, as it attempts to answer the research question: What are the implications brought about by the fabrication of messages produced by the "center" for the "periphery" when other communication instruments are "anemic"? 


\section{METHODOLOGY}

The methodology used in this paper is closely related to the interpretation of the data obtained from secondary sources. These sources are the basis of theoretical material that I have received over the years of my academic studies, as well as information collected from scientific journals, national and international institutions, Internet, etc. Based on the reliability of these data, I have reached the conclusion given at the end of this paper.

\section{HEGEMONISC REPRODUCTION DUE TO THE EFFECT STRUCTURING SPEECH BY SOME MEDIA POWERFULL}

As we are aware, up to 1990 - 1991 Albania and former Yugoslavia were divided by "high walls", and real contacts between Albanians on both sides of the border were virtually impossible. For decades, as a result of lack of contacts, mutual imagination remained mostly at a fictional and romantic level that sometimes could take an almost mythological dimension [4].

After '90s, the development of electronic media market in Albania began to be seen at the Albanians across the border as a source of promotion of national symbols. Despite the fact that the development of this market was conditioned by poor infrastructure, some media were transformed in a short time in important primary sources for the pan-Albanian information. Companies such as Top Media, Media 6, Grupi Edisud and Media Vision, finding themselves among poor local and regional media from the financial and professional aspects, became in a short time important information centers within and outside the Albanian territory.

These media left behind the obstacles formed by divisions created in decades and deepened during the totalitarian system, and started to appeal to the general interest [5]. .Messages distributed by these media and intensive exchange of experiences and ideas were considered as the most effective ways to achieve common stances, coordination of actions, provision of models and solutions for facing the challenges of the reality" [6]. These media companies, based on the motto "Think regionally but act locally", began to develop businesses with clear geo-linguistic and geo-cultural orientation.

This happened in a short period of time and created a model of pan-Albanian integration, cultivating common linguistic standards, cultural products with national nuances, stimulation of homogenous thinking and expanded pan-Albanian symbolic space [7].

This communicative dimension, enabled especially by television, recreates to some extent a kind of equality of relationship of the citizens wherever they reside, and the cultural and artistic processes at regional and local level [8]. Inside and outside the Albanian political territory, the audience could see alike the same cultural and political activities. Despite the fact that for some communication specialists this media reality with national nuance is considered very positive in terms of information exchange and standardization of social conventions, the risks behind this reality, cannot be underestimated [9].

Powerful channels based in Tirana, such as Top Cannel, Klan, ABC News, Vision Plus, Ora News, News 24 etc., began to have a great impact on the program structuring of the media in Kosovo and Western Macedonia. It can even be said that often broadcasting formats aired in any channel in these Albanian-speaking regions looked like a "copy paste" of the programs of Top Channel and Klan televisions.

This impact is most obvious if we refer to formats of political broadcasts. Also, the influence of these powerful channels based in Tirana - the "center" - is noticed not only in 
their programs, but also in their television coverage time available for the presentation and the analysis of problems associated with the "periphery". Television coverage time is dominated - for commercial and technical reasons - by problems related to the "center" and less time is available for the "periphery".

This asymmetry is easily noticed if we refer to the television time available for treating problems related to the "center" and "periphery" during the broadcast of the news in Top Channel and Klan televisions. Based on direct personal observations of these channels, I can conclude that available time coverage for topics related to Kosovo, Macedonia and Montenegro varies from $5 \mathrm{~min}$ to $10 \mathrm{~min}$.

In addition, results of surveys conducted by international and local institutions highlight the fact that prime time news (at 7:30 p.m.) of the main channels, such as Top Channel and Klan, have an audience reaching $80 \%$ in Kosovo and $99 \%$ in Macedonia. Given this high level of audience, the above companies have opened offices in Pristina and Skopje for further expanding the coverage of topics in these areas.

Another important aspect of the media influence is that, in such realities, the individual or the social group in peripheral areas, being under the influence of electronic media, might become merely a passive viewer of cultural and artistic achievements [10].

Models imposed by the "center" become the object of consumption for residents of the "periphery". Under such circumstances, the culture and the autochthonous local art begins to fade its significance and therefore cultural treasures of the domestic culture are rapidly "shrunk" to the benefit of information and cultural and artistic values fabricated by the "center", namely all that occupies the screen [11].

\section{CONCLUSION}

In general, these broadcasting "centers" fabricate linguistic and cultural standards and the "periphery" becomes their "final destination". This process undermines the emergence of different dialects, mentalities and perspectives.

Furthermore, due to lack of getting knowledge from artistic and scientific books, written press, specialized academic journals, pedagogical education practices in rural areas as well as in Macedonia, Kosovo and Montenegro, television starts to acquire the status of the only source for transmitting culture. And when the above components are missing or do not play their "filtering" role toward the message broadcasted by the television, the latter becomes their "spokesman", creating thus only its specific patterns or models.

Therefore, the need for television and the recognition of problems stemming from its functions should be broadly treated in order to put into operation other social mechanisms. Moreover, as mentioned very often, television cannot be either an educational institution or a cultural center and can never replace their roles. 


\section{References}

[1] Adams B. (2004). Geographies of Media and Communication, Malden, MA: Wiley Blackwell.

[2] Chomsky N. (1991). Media control: the spectacular achievements of propaganda. New York: Open Media Pamphlet.

[3] Altheide D. (1985). Media Power, Beverly Hills: Sage.

[4] Misha P. (2008). Arratisje nga burgjet e histories, Tiranë: Toena

[5] Thiesse M. A. (2004). Krijimi i identiteteve kombëtare, Tiranë: Dukagjini

[6] Gjergji B. (2009). “Komunikimi bashkëkohor midis shqiptarëve”, Revista e Departamentit te Gazetarisë. Tirane.

[7] Gjergji B. (2009). Komunikimi bashkëkohor midis shqiptarëve, Revista e Departamentit te Gazetarisë. Tirane.

[8] Chomsy N. (1991). Media control: the spectacular achievements of propaganda, New York: Open Media Pamphlet.

[9] Leydesdorff L. (2001). A Sociological Theory of Communication the Self Organization of the Knowledge - Based Society, SHBA: Universal Publishers/unPublish.Com.

[10] Myle F. John (2010). Bourdieu, Language and The Media, Great Britain Palgrave MacMillan

[11] Maigret E. (2003). Sociologie de la communication et des médias, Paris, Éditions Armand Colin. 